\title{
Liability and Compensation for Damages in Case of Violation of the Principles of Accountability and Good Governance ${ }^{1}$
}

\author{
Tina Sever \\ University of Ljubljana, Faculty of Administration, Slovenia \\ tina.sever@fu.uni-lj.si
}

ABSTRACT:

Accountability is one of the fundamental principles of good governance, defined in various international documents. It is a broad term, which can include different levels of public administration performance, from organisation, relevant regulation, internal and external supervision, transparency to tort liability, etc. The paper focuses on procedural aspects, i.e. decision-making in administrative matters. The latter is usually regulated by an administrative procedure act, which can include among fundamental principles also the principle of accountability. However, other procedural guarantees, e.g. lawfulness, equality, impartiality, proportionality, legal certainty, taking action within a reasonable time, contribute to responsible decision-making as well. In case they are infringed, the state should recognise accountability and have in place an efficient control system providing parties with effective (legal) remedies (e.g. possibility to appeal to the line ministry; administrative inspection; judicial control; constitutional complaint, compensation, etc.). Yet, not every non-compliance (irregularity) leads to (tort) liability. Administrative authorities in fact enjoy a high level of independence. The paper provides an international overview of accountability and analyses the liability of the state as deriving from the Slovene domestic law and the levels of accountability when the efficiency of administrative procedures is under question. The methods used include normative analysis and analysis of the relevant case law.

Key words: accountability, administrative procedure, compensation, public official, Slovenia, good administration.

$J E L: K 4$

1 This article is a revised version of the paper entitled 'Accountability of public officials as a key element of good governance - case of Slovenia', presented at the NISPAcee Conference, Zagreb, May 19-21, 2016. The NISPAcee contributions are not publicly available. 


\section{Introduction}

Administrative law is part of public law and, as such, left to the states' sovereignty when it comes to its regulation. However, with the EU accession and the enforcement of the acquis communautaire, there is a need to define certain principles and rules on the EU level, creating a common European Administrative Space (EAS) and contributing to a certain level of convergence. Namely, in accordance with the minimum standards of effectiveness to prevent discrimination in practice, the parties should have access to public administration services regardless in which Member State they require certain rights (cf. Kerševan, 2004). The core principles of European administrative law can be systemised in the following groups: 1) reliability and predictability, 2) openness and transparency, 3) accountability, and 4) efficiency (SIGMA, 1999, p. 8). These four groups comprise numerous administrative law principles, either of procedural or substantive nature, such as lawfulness, equality, proportionality, objectivity and impartiality, protection of legitimate trust, right to be heard, representation and assistance, time limits, the duty to give reasons for decision-making, etc. (see Table 1; more on principles cf. also Sever et al., 2014). Their violation can lead to a case of accountability. However, not every violation leads to (tort) liability, but it certainly gives grounds to apply legal remedies (see Table 1).

The paper deals with the following research questions: firstly, the concept of accountability in the supranational context, with special focus on administrative procedural requirements as deriving from the concept of good governance; secondly, the incorporation of supranational requirements, i.e. the 2017 SIGMA Accountability Principles of Public Administration, within the Slovene regulation and Public Administration Strategy 2015-2020; and thirdly, the requirement to conduct procedures within a reasonable time as one of the preconditions for an effective and responsible public administration (case of Slovenia). In this respect, the aim of the paper is to analyse the requirements and principles of accountability within the supranational framework and in the case of Slovenia. The paper addresses accountability as part of good governance and studies its relevance for the lawfulness of administrative procedures, especially in terms of timely decision-making and available redress in case of infringement (state liability for damages leading to duty of damage compensation). The goal of the paper is to provide an analysis of the Slovene regulation, with special focus on the responsibility of public officials to conduct administrative procedures effectively without undue delay. The main methods used include normative analysis and analysis of the relevant case law.

The paper first outlines the existing supranational documents in terms of their "interpretation" of the accountability concept. In the second chapter, the Slovene Public Administration Strategy 2015-2020, focusing on administrative procedures, is examined in relation to the SIGMA 2017 accountability principles. Moreover, the right to compensation for damage caused through unlawful actions by authorities is analysed. The last chapter is dedicated to conducting procedures within a reasonable time as one of the preconditions for an effective and responsible public administration. 
Table 1. Administrative law principles

\begin{tabular}{|l|l|}
\hline \multicolumn{2}{|c|}{ Principles } \\
\hline \multicolumn{1}{|c|}{ Substantive law principles: } & \multicolumn{1}{c|}{ Procedural law principles: } \\
\hline $\begin{array}{l}\text { Lawfulness, equality before the } \\
\text { law, conformity to statutory aim, } \\
\text { proportionality, objectivity and } \\
\text { impartiality, protection of legitimate } \\
\text { trust and vested rights, openness. }\end{array}$ & $\begin{array}{l}\text { Access to public services, right } \\
\text { to be heard, representation and } \\
\text { assistance, time limits, notification, } \\
\text { statement of reasons and indication } \\
\text { of remedies, execution of } \\
\text { administrative acts. }\end{array}$ \\
\hline \multicolumn{2}{|c|}{ If violation by administrative authorities } \\
\hline \multicolumn{2}{|c|}{ Possible legal remedies: appeal, extraordinary legal remedies, } \\
judicial review
\end{tabular}

Source: based on Administration and You, Council of Europe, 1996

Accountability is a broad concept, emphasised in the public sector through various international documents (for its inclusion in different international documents, see Table 2) giving several (obligatory) recommendations to national authorities. However, the actual content of the term "accountability" seems to vary. Sometimes, the term is used separately, but usually there is also a connection to transparency and openness (see Table 2). Accountability can in general mean one institution being accountable to another (internal control) as well as being liable for wrongdoing or omission in relation to the parties (external dimension) (Venice Commission, 2011, p. 11; cf. SIGMA, 1999, pp. 12-13). As mentioned above, it is one of the main principles of European administrative law. Thus, in case of misconduct of the administration, the latter should compensate the victims of such action (Woehrling, 2006, p. 9). Therefore, clear rules on the expected and allowed behaviour of the public administration (PA) when deciding on the parties' rights and obligations are a precondition of accountability. Most countries define the vast majority of administrative law principles and rules by an administrative procedure act (APA) (see for example Germany (1976), Austria (1991), Netherlands (1994), Estonia (2002), Finland (2003), Czech Republic (2004), France (2015), etc.; cf. Sever et al., 2014). Since administrative procedure is the main business process of public administration, the principle of accountability is also among the general principles of administrative activity to be included in the APA following the instructions on APA regulation (see Cardona, 2005, p. 6). Finally, in order to make public administration accountable, effective supervision is needed. One form of control are the legal remedies defined by the APA, which can be enforced either ex officio or on party's request. Moreover, there is also 
the possibility of judicial review and of submitting a request for supervision to competent inspectorates, ombudsmen, etc. (cF. SIGMA, 1999, pp. 12-13).

Table 2. Accountability in the (supra)national context

\begin{tabular}{|c|c|c|}
\hline Act (year) & Content & Consequence \\
\hline $\begin{array}{l}\text { SIGMA Principles of Public } \\
\text { Administration (2017) }\end{array}$ & $\begin{array}{l}\text { Accountability as part of overall } \\
\text { framework in PA (reform) } \\
\text { requires liability and transparency } \\
\text { of state administration bodies } \\
\text { and is elaborated further in } 5 \\
\text { subprinciples (for details see } \\
\text { Table } 3 \text { in chapter } 2 \text { ) } \\
\text { (Recommendation to national } \\
\text { level*). }\end{array}$ & $\begin{array}{l}\text { Redress and/or adequate } \\
\text { compensation. }\end{array}$ \\
\hline $\begin{array}{l}\text { Stocktaking on the Notions } \\
\text { of "Good Governance" and } \\
\text { "Good Administration", Venice } \\
\text { Commission (2011) }\end{array}$ & $\begin{array}{l}\text { Accountability as part of good } \\
\text { governance concept (GG). } \\
\text { GG encompasses good } \\
\text { administration and includes also the } \\
\text { following elements: Transparency, } \\
\text { responsiveness to people's needs, } \\
\text { efficiency, effectiveness, openness, } \\
\text { participation, predictability, rule, } \\
\text { of law, coherence, equity, ethical } \\
\text { behaviour, combating corruption, } \\
\text { termination of proceedings within } \\
\text { a reasonable time, protection of } \\
\text { human rights, simplification of } \\
\text { procedures. } \\
\text { Overview of principles based on } \\
\text { analysis of national and supra- } \\
\text { national documents. }\end{array}$ & / \\
\hline $\begin{array}{l}\text { EU Charter of Fundamental } \\
\text { Rights (2010) }\end{array}$ & $\begin{array}{l}\text { Right to compensation } \\
\text { for any damage caused by } \\
\text { EU institutions/servants in } \\
\text { accordance with the general } \\
\text { principles common to Member } \\
\text { States law (supra- and national } \\
\text { level, when implementing EU law). }\end{array}$ & Possible compensation. \\
\hline $\begin{array}{l}\text { Council of Europe } \\
\text { Recommendation CM/Rec(2007)7 } \\
\text { on good administration }\end{array}$ & $\begin{array}{l}\text { Unlawful administrative } \\
\text { decision or negligence on the } \\
\text { part of administration or its } \\
\text { officials calls for compensation } \\
\text { (recommendation to national } \\
\text { level, to member states). }\end{array}$ & $\begin{array}{l}\text { Compensation: party should } \\
\text { seek to resolve dispute with the } \\
\text { concerned authorities before } \\
\text { bringing action for compensation } \\
\text { to the courts. }\end{array}$ \\
\hline $\begin{array}{l}\text { EU White Paper on European } \\
\text { Governance (2001) }\end{array}$ & $\begin{array}{l}\text { Accountability: clearer roles } \\
\text { in legislative and executive } \\
\text { processes; EU institutions \& } \\
\text { member states taking the } \\
\text { responsibility to perform duties } \\
\text { (both levels, national and supra- } \\
\text { national). } \\
\text { Besides accountability, also } \\
\text { other GG principles: openness, } \\
\text { participation, effectiveness and } \\
\text { coherence - altogether underpin } \\
\text { democracy and the rule of law in } \\
\text { member states, applicability to } \\
\text { all levels of government (global, } \\
\text { European, national, regional and } \\
\text { local). }\end{array}$ & / \\
\hline $\begin{array}{l}\text { Council of Europe } \\
\text { Recommendation No. R (84) } 15 \\
\text { on Public liability }\end{array}$ & $\begin{array}{l}\text { Public liability for damage caused } \\
\text { by action or omission to act by } \\
\text { public authority** (national level). }\end{array}$ & $\begin{array}{l}\text { Reparation (i.e. compensation or } \\
\text { other appropriate means). }\end{array}$ \\
\hline
\end{tabular}

" Overall, the extent to which candidate countries apply these principles in practice indicates whether their national public administration is capable to implement the acquis effectively (see The Principles of Public Administration, 2017, p. 7).

** See Appendix to Recommendation No. R (84) 15, Scope and Definitions: "The term „public authority“ means: a. any entity of public law of any kind or at any level (including state; region; province; municipality; independent public entity); and b. any private person, when exercising prerogatives of official authority."

\section{Source: documents as deriving from Table 2}


Furthermore, accountability is one of the key requirements of the notion of good governance (see Table 2). Organisations are accountable to the subjects who will be affected by their decisions or actions. The World Bank first used the concept of good governance in the 1990s, being inspired by economic considerations in terms of quality of the countries' government systems and the ability to pursue sustainable economic and social development (Venice Commission, 2011, p. 3) ${ }^{2}$. Since this view disregarded some aspects of democracy, the concept was later on adapted and developed by other international institutions. According to the findings of the Venice Commission (2011, p. 4), the concept of good governance is a rather non-legal concept since it is not part of the legal orders of the Council of Europe member states. A part of good governance is also the principle of (the right to) good administration (GA), which includes several procedural rights enshrined in international documents and national legal orders (Venice Commission, 2011, p. 4; cf. Table 2). Good administration also refers to some of the rights deriving from Article 6 of the European Convention on Human Rights (ECHR), which is of utmost importance as regards conducting procedures within a reasonable time, a precondition of effective and consequently responsible public administration. ${ }^{3}$ The concept of GA includes principles such as impartiality, fairness, termination of proceedings within a reasonable time, legal certainty, proportionality, non-discrimination, right to be heard, effectiveness and efficiency (cf. Table 2), which all contribute to a responsible PA.

According to a recent document by SIGMA (The Principles of Public Administration, 2017), accountability requires lawful performance by state administration bodies in different fields. Firstly, in terms of rational organisation, it is necessary to pursue adequate policies and regulations and provide for proper internal, political, judicial, social and independent accountability (SIGMA, 2017, p. 55). Secondly, besides liability for wrongdoing and guarantee of redress (and/or adequate compensation), accountability also encompasses the right of access to public information (openness and transparency) and an effective mechanism to protect the individual's right to good administration and the public interest. Finally, fair treatment by means of internal administrative appeals and judicial review should be ensured (SIGMA, 2017, P. 55).

\section{Accountability of Public Officials in Slovenia}

Although the principles of public administration as set by SIGMA in 2017 are primarily meant for the candidate countries or potential candidates within the EU enlargement process, these principles in general present standards of good public administration within the EAS. Moreover, they provide a valuable framework with defined methodology and indicators to assess the state of affairs and the needs for improvement of the existing administrative systems in the EU Member States (Virant, 2015, p. 1). The paper mostly focuses on accountability principles within administrative procedures (see Table 3).

2 CF. also Vanebo and Andersen (2014) on principles of new public management, pp. 9-20.

3 On efficiency and accountability, see SIGMA 1999, p. 13. 
Table 3. Accountability principles in the European Administrative Space as set by SIGMA in 2017 and in Slovenia

\begin{tabular}{|c|c|}
\hline $\begin{array}{l}\text { SIGMA } 2017 \text { - Accountability Principles \& } \\
\text { Requirements }\end{array}$ & $\begin{array}{l}\text { Slovenia - with a focus on administrative } \\
\text { procedures }\end{array}$ \\
\hline $\begin{array}{l}\text { Principle 1: } \\
\text { The overall organisation of central government } \\
\text { is rational, follows adequate policies and } \\
\text { regulations and provides for appropriate } \\
\text { internal, political, judicial, social and } \\
\text { independent accountability. }\end{array}$ & $\begin{array}{l}\text { In terms of scope, the merging of certain } \\
\text { ministries/fields should be reconsidered. } \\
\text { Accountability is provided by different } \\
\text { mechanisms: } \\
\text { - political: e.g. parliamentary questions; } \\
\text { - parliamentary scrutiny; } \\
\text { - internal: second-instance administrative } \\
\text { appeal (to line ministry); } \\
\text { - judicial review; } \\
\text { - constitutional complaint; } \\
\text { - possibility to address administrative } \\
\text { inspection, ombudsman. }\end{array}$ \\
\hline $\begin{array}{l}\text { Principle 2: } \\
\text { The right to access public information is } \\
\text { enacted in legislation and consistently applied } \\
\text { in practice. }\end{array}$ & $\begin{array}{l}\text { Adequate Public Information Access Act, } \\
\text { which functions in practice: access to public } \\
\text { information and appeal to Information } \\
\text { Commissioner. Due to corruption problems* } \\
\text { certain improvements are envisaged by } \\
\text { PA Strategy for 2015-2020: higher level of } \\
\text { citizens' participation in rulemaking; better } \\
\text { connection of different databases; upgrading } \\
\text { the systems of control over transactions in } \\
\text { public sector, etc. }\end{array}$ \\
\hline $\begin{array}{l}\text { Principle 3: } \\
\text { Functioning mechanisms are in place to protect } \\
\text { both the rights of the individual to good } \\
\text { administration and the public interest. }\end{array}$ & $\begin{array}{l}\text { Mostly by implementing APA principles and } \\
\text { rules. } \\
\text { See Principle } 1 \text { above. }\end{array}$ \\
\hline $\begin{array}{l}\text { Principle 4: } \\
\text { Fair treatment in administrative disputes is } \\
\text { guaranteed by internal administrative appeals } \\
\text { and judicial reviews. }\end{array}$ & Yes. See Principles 3 and 1 above. \\
\hline $\begin{array}{l}\text { Principle 5: } \\
\text { Public authorities assume liability in cases of } \\
\text { wrongdoing and guarantee redress and/or } \\
\text { adequate compensation. }\end{array}$ & $\begin{array}{l}\text { Recognition of state liability already at the } \\
\text { constitutional level. However, not so many } \\
\text { cases in practice. }\end{array}$ \\
\hline
\end{tabular}

*E.g. on corruption analysis in Slovene administration see Pečarič, Benčina and Kozjek, 2017.

Source: SIGMA Principles of Public Administration (2017) and the Slovene Public Administration Strategy 2015-2020

As we can see in Table 3, SIGMA interconnects different elements of PA in terms of accountability principles, from organisation, proper policymaking and regulation to internal and external supervision, liability and redress, access to information, transparency, fair treatment in procedures, etc. Overall, Slovenia fulfils these requirements (see Table 3). However, the new PA Strategy envisages certain improvements for 2015-2020, such as merging of certain services and offices, a one-stop shop for the users, centralisation of management and more transparent implementation of public procurement, modernisation of administrative and inspection procedures, open and transparent operation with zero tolerance to integrity violation in the public sector, etc. (for details see Public Administration Strategy 2015-2020). 
For the purpose of this paper, we focus on the conduct of administrative procedures and, in this respect, the liability of the state. Of course, there are also other relevant situations in terms of state liability, such as issuance or execution of general acts and performing real substantive acts. Furthermore, besides tort liability, there are other kinds of liability, such as criminal and misdemeanour liability, and liabilities related to work, e.g. disciplinary liability, liability for work results, violation of the work code, etc. (Virant, 2010, pp. 62-63; cf. Sever, 2015, pp. 129-130).

The tort liability of the state has its origins in Article 26 of the Slovene Constitution (Official Gazette of RS, No. 33/91-I and amendments). According thereto, everyone is entitled to compensation for damage caused by unlawful action in connection with the performance of any function or other activity by a state authority, local authority, or bearer of public authority (see Table 4). Such unlawful action can be carried out by either a person or a body performing a certain function or the "administrative machinery" (see Constitutional Court Decision No. Up-695/11-15, 10 January 2013). The constitutional provisions do not explicitly define guilt. According to the Constitutional Court, Article 26 covers all different kinds of unlawful actions of the state and has the nature of lex generalis. The compensation deriving from Article 26 of the Constitution is classic compensation for either pecuniary or non-pecuniary damage and the general rules of torts law set by the Code of Obligations (CO, Official Gazette of RS, No. 83/01 and amendments) apply. For the establishment of tort liability of the competent authorities, the following procedural preconditions need to be fulfilled: unlawful action by a person or body causing damage (actual and loss of profit) and a causal link between the unlawful action and the damage caused. As regards guilt, theory offers different views, advocating either an objective (see for example Pirnat, 2005, p. 27: only when manifestly and clearly unlawful) or a subjective approach (e.g. Bukovec, 2005, pp. 43-48: requiring guilt, i.e. the state is not liable when proved that the public official acted with the diligence of an expert).

Table 4. Right to compensation for damages under Article 26 of the Slovene Constitution

\begin{tabular}{|l|l|}
\hline \multicolumn{2}{|c|}{ Article 26 of the Slovene Constitution } \\
\hline WHO has the right to compensation? & $\begin{array}{l}\text { Anyone (natural persons, legal persons, } \\
\text { group of citizens). }\end{array}$ \\
\hline WHEN? & $\begin{array}{l}\text { Damage because of unlawful action in } \\
\text { connection with the performance of } \\
\text { any function or other activity by state } \\
\text { authority, local authority, or bearer of } \\
\text { public authority. }\end{array}$ \\
\hline WHO is liable? & $\begin{array}{l}\text { Person or body performing function or } \\
\text { activity. }\end{array}$ \\
\hline GUILT? & Not explicitly stated. \\
\hline
\end{tabular}

Source: Slovene Constitution 
In our opinion, when conducting administrative procedures, the liability of the state as deriving from Article 26 should be reconsidered as objective liability, taking into account also subjective elements, i.e. due diligence standards. In general, unlawful action is determined based on non-compliance with the law. However, not every non-compliance (irregularity) leads to tort liability. Administrative authorities in fact enjoy a high level of independence (see Article 2 of the State Administration Act $^{4}$ and Articles 12 and $6 \S 2$ of the APA). Two officials are usually involved in an administrative procedure. One is responsible to conduct the procedure. He or she needs to have an adequate level of education and must have passed the state examination in administrative procedure. This official signs the final decision on the left side. The official responsible for decision-making signs the administrative decision on the right side. He or she is usually the Head of the competent body and does not need to have passed the state examination in administrative procedure. The Head can authorise for decision-making also some other official employed by the same body. Such authorisation may include the authorisation to conduct the administrative procedure or to perform only certain activities. An inspector, for example, is authorised by law to decide in administrative matters (see Article 28 of the APA). Nevertheless, they are all obliged to respect the fundamental administrative law principles of legality, independence and substantive truth, as defined by the APA. Consequently, giving instructions on how to decide in a particular matter is prohibited (general instructions concerning the interpretation of law, work, etc. are excluded from such prohibition). If a public official finds an instruction unclear or the execution thereof could lead to unlawful action or damage, he or she can request a written instruction. Moreover, he or she can reject execution if such action would lead to unlawful action. If it would lead to a criminal offence, he or she is obliged to reject execution (see Article 94 of the Civil Servants Act) (see Sever, 2015, p. 128).

The assessment of unlawfulness is based on the nature of performance, for example, if a body, when performing its functions, fails to apply due diligence to such an extent that its action becomes unlawful. However, performance is not unlawful only because a second-instance body changed, annulled or abrogated a first-instance administrative decision (e.g. due to wrongfully assessed facts of the case). On the contrary, it has to be manifestly and clearly unlawful (e.g. arbitrary non-application of certain rules; manifested violation of clear rules) (Sever, 2015, pp. 122-123). Also arbitrariness in performing discretionary powers can be unlawful (Bukovec, 2005, p. 47), or prejudicing the rights without a legal basis. In such case, the inconsistency between sectoral legislation and the circumstances of the case has to be obvious and not negligible. Furthermore, each deviation from case law or practice does not mean tort liability of the state (Sever, 2015, pp. 123-124). Namely, a judge or other public official can consciously deviate from case law or practice when legally determining their decision. However, if such deviation is a consequence

4 Official Gazette of RS, No. 52/02 and amendments. 
of insufficient legal knowledge and leads to a decision that otherwise no reasonable public official would issue, then he or she could be held liable (Bukovec, 2004, p. 1194; Bukovec, 2005, p. 48).

Finally, a public official may be held liable for the damage he or she deliberately or out of serious negligence caused to the employer at work or in connection therewith. Likewise, the employer is accountable for the damage that the public official caused to a third person at work or in connection therewith. The employer can request a recourse from the employee when the damage to the third person was caused deliberately or out of serious negligence (see Articles 135-139 of the Civil Servants Act, Official Gazette of RS, No. 56/02 and amendments). In case of deliberately caused damage, the third person can request restitution of damage directly from the public official. In this respect, the provisions of the Civil Servants Act implement the constitutional provisions. Similarly, also the Inspection Act (Official Gazette, No. 56/02 and amendments) defines tort liability of the state or a self-governing local community for unlawful act or omission by an inspector (see Article 37). The Act itself focuses only on pecuniary damage that can occur during the inspection. Similarly, the state or a self-governing local community can request a recourse from the employee when the damage to the third person was caused deliberately or out of negligence. However, the third person can request restitution of damage directly from the inspector only in case damage was caused due to a criminal offence. However, if the public official causes a disciplinary violation or damage as a result of executing a written instruction or order given by his or her superior, he or she is free of tort and disciplinary liability. In this case, the superior is held liable (see Articles 94 and 138 of Civil Servants Act).

Namely, the authorities are responsible to conduct certain tasks. In case these tasks are performed improperly or unlawfully, they can be held accountable. In this respect, it can be presumed that responsibility is a precondition of accountability. Law defines both. It sets a legal framework for responsibility, i.e. who is competent to perform which (administrative) activities, in what time, by applying which means, etc. In case of infringements, law provides legal structures of accountability. In this respect, the steering function of law is important, determining competences, organisation and procedure (e.g. administrative organisational law, administrative procedural law etc.) (cf. Schuppert, 2007, p. 42). By setting up the accountability principles, the state defines the framework (structure provided by law). Such framework is not yet a guarantee that the tasks will be performed in a certain way in the end, but it nevertheless enables control of the performed tasks (cf. Schuppert, 2007, pp. 43-44).

\section{Effective and Responsible Public Administration Conducting Procedures within a Reasonable Time}

In accordance with the principle of economy (Article 14 of APA), administrative procedures need to be conducted rapidly, within a reasonable time, and with 
minimum costs. In case of delays, the party has the right to file an appeal on grounds of administrative silence (see Article 222 of the APA). When there is a double administrative silence (also at the second instance) and despite the party's urgency no response is given, the party can file action on grounds of administrative silence to the specialised Administrative Court (see Article 28 of the Administrative Dispute Act, Official Gazette of RS, No. 105/06 and amendments). According to the ECtHR case law, these legal remedies are efficient and the parties need to exhaust them (see ECtHR Partial Decision Sirc v. Slovenia, No. 44580/98, 8 April 2008; cf. ECtHR Decision Štajcar v. Croatia, 46279/99, 20 January 2000). In case of passivity, a part of the occurred damage can be attributed to the party itself. Namely, failure to observe the time limits is definitely an aspect of irregularity and maladministration, but it does not necessarily mean unlawfulness (Sever, 2015, p. 135).

Moreover, the obligation of timely decision-making applies to all stages and branches of power, i.e. besides the first- and second-instance administrative procedures also court procedures. Such obligation derives from the Slovene Constitution (see Articles 23 and Articles 120 in connection with Article 22) as well as from Article 6 of the ECHR, which since 1994 has been binding also for Slovenia. Furthermore, Article 13 of the ECHR requires effective legal remedies already at the national level in case of violations of Article 6, e.g. unreasonably long procedures. Legal remedies can be either preventive or compensatory for already occurred violations, or the domestic legal system can introduce a combination of both. Only after the exhaustion of domestic legal remedies the parties can file an application to the European Court of Human Rights (ECtHR) (see Article 35 of the ECHR). However, the right to compensation, as deriving from Article 26 of the Slovene Constitution, cannot be equated with the request for effective legal remedy or compensation as specified by the ECHR (Sever, 2015, p. 131).

In such regard, the ECtHR noted a systemic problem in Slovenia due to inadequate legislation and inefficiency of justice administration that led to unreasonably long procedures (see quasi-pilot judgment in the Lukenda case, No. 23032/02, 6 October 2005). Consequently, in order to improve the system's efficiency, the state adopted a new law, i.e. the Protection of Right to Trial without Undue Delay Act (UDA, Official Gazette, No. 49/06 and amendments). This new law recognises procedural and substantive protection of the right to timely decision-making (see Articles 1 and 2 of UDA; Sever, 2015, pp. 131-132). It enacts the legal remedies to speed up judicial procedures and compensation for occurred delays.

When deciding on their application in case of unreasonably long procedures, the circumstances of the case are assessed using the same criteria as developed through ECtHR case law (see Grzinčič v. Slovenia, No. 26867/02, 3 May 2007, раг. 97). That includes the circumstances of the individual case, especially its actual and legal complexity, the parties' action during procedure (in terms of fulfilling the procedural rights and obligations), the respect of the rules on legal order and the time limits to perform tasks at the court, the 
nature and type of the matter and its meaning for the party (Article 4 of UDA). The UDA defines objective liability for pecuniary and non-pecuniary damage (Grzinčič v. Slovenia, No. 26867/02, 3 May 2007, par. 96). Therefore, for nonpecuniary damage, the establishment of violation of the right to a fair trial within a reasonable time - besides the established damages and the causal link - suffices. In terms of state liability for violation of the right to a fair trial within a reasonable time, the UDA is lex specialis (Urbančič, 2012, pp. II, Vl; cf. Sever, 2015; Sever et al. 2016). Consequently, the general provisions of the CO apply only when the UDA does not regulate certain questions. However, when the parties allege pecuniary damage, the UDA refers to the application of CO provisions.

Overall, the Slovene regulation follows the ECHHR assumption of existence of non-pecuniary damage when there is a violation of the right to trial without undue delay. Domestic courts are obliged to respect this assumption (see Urbančič, 2012, p. VI, Order No. U-I-1/10-6, Up-1315/09-10, 20 January 2011). Of course, it is possible that in some cases, there is no damage or the latter is only minimal, therefore a violation of the right to a fair trial without undue delay does not always lead to non-pecuniary damage. In such case, the court needs to state that there was no damage or that it was only minimal (Urbančič, 2012, p. III). Finally, according to the ECtHR case law, action for damages as defined by the UDA is an efficient legal remedy even when it is the only legal remedy available because the violation of the right to trial without undue delay ended before the start of UDA application. ${ }^{5}$

In terms of conducting procedures within a reasonable time, we conclude that the authorities and the party itself share part of the necessary diligence, meaning that the authority should strive for lawfulness and speediness while the party should not extend the procedures with unnecessary, changing requests or negligence.

\section{Conclusion}

The problem with administrative legal principles is their dispersion among different acts, from the constitution to acts regulating administrative procedures, public administration organisation, performance of public officials, etc. The inconsistency of regulation can create a certain level of uncertainty and opacity among the parties and the officials. Accountability is (internationally) mostly mentioned in terms of the good governance concept. However, the term has different meanings and can include various fields of PA performance. The paper focused mainly on a responsible conduct of administrative procedures. In such regard, good administration is also an important part of good governance, since it is of legal nature and encompasses several procedural guarantees as deriving from the APA, such as lawfulness, equality, impartiality, proportionality, legal certainty, taking action within a reasonable time, transparency, etc. In this context, it can be

5 See ECtHR Decision Korenjak v. Slovenia no. 463/03, 15 May 2007, par. 60; ECtHR Decision Zajc et al. v. Slovenia, 13992/03, 33814/03, 37190/03, 3088/03, 38847/04, 6 May 2008, раг. 43-45. 
logically assumed that a breach of APA principles and rules can lead to a certain level of accountability. Mostly procedural mistakes are corrected by applying legal remedies in the administrative procedure itself or in judicial review. However, if mistakes are a result of deliberate wrongful action or negligence, the parties can also claim compensation. Finally, the state can sometimes also be objectively liable (e.g. non-functioning of judicial system, causing unreasonably long procedures). In our opinion, the principles of accountability are definitely a precondition of the democratic state, ensuring protection of private parties in their relation with the authorities, and should as such be recognised as fundamental principles in national legislation, e.g. a new APA as envisaged by the PA Strategy 2015-2020.

Tina Sever is an Assistant Professor at the Faculty of Administration, University of Ljubljana (UL). In 2006, she obtained an LL.B. from the Faculty of Law of the University of Ljubljana and in 2014 a PhD from the European Faculty of Law. In 2007 and 2008, she worked as a trainee in the Administrative Unit of Ljubljana, at the European Commission (Directorate General for Translation in Luxembourg), as well as at the European Ombudsman. She completed a Bar Examination Traineeship at the Higher Court of Ljubljana in 2009. In October 2008, she started to work as a Teaching Assistant at the University and was appointed Assistant Professor in December 2016. She publishes and conducts research in the fields of public administration and administrative law. 


\section{References:}

Bukovec, M. (2005). Odškodninska odgovornost države za svoje uslužbence [Tort liability of the state for its officials]. In Odgovornost države, lokalnih skupnosti in drugih nosilcev javnih pooblastil za ravnanje svojih organov in uslužbencev [Liability of the state, local communities and other bearers of public authority for the performance of their bodies and officials], pp. 41-50. Edited by Mojca Seliškar Toš. Ljubljana: Inštitut za primerjalno pravo pri Pravni fakulteti.

Bukovec, M. (2004). Odškodninska odgovornost države [Tort liability of the state]. Paper presented at the Dnevi slovenskih pravnikov, October 14-16. Portorož, Slovenia (pp. 1182-1197).

Cardona, F. (2005). Checklist for general law on administrative procedures. SIGMA. http://www.sigmaweb.org/publicationsdocuments/37890936.pdf (accessed October 20, 2017).

Council of Europe, Recommendation No. R (84) 15 of the Committee of Ministers relating to public liability, 18. 9. 1984.

Council of Europe, Recommendation CM/Rec(2007)7 of the Committee of Ministers to member states on good administration, 20. 6. 2007.

Council of Europe. 1996. The Administration and you. Principles of administrative law concerning the relations between administrative authorities and private persons. Strasbourg: Council of Europe.

EU Charter of Fundamental Rights. 2010. Official Journal EU C, No. 83/389, 30 March 2010.

European Principles for Public Administration, SIGMA papers No. 27, CCNM/ SIGMA/PUMA(99)44/REV1, SIGMA - OECD, 22. 11. 1999.

EU White Paper on European Governance. 2001. COM(2001) 428 final, 25 July 2001.

Kerševan, E. (2004). European administrative procedure in national administrative framework. Four months after administering the new Europe. Paper presented at the European Group of Public Administration - EGPA [Annual Conference], 1-4 September. Ljubljana, Slovenia (pp. 1-12).

Pečarič, M., Benčina, J., Kozjek, T. (2017). Zaznava korupcije v slovenski državni upravi [Identification of corruption in Slovene state administration]. Revija za kriminalistiko in kriminologijo, 68(2), 150-165.

Pirnat, R. (2005). Protipravnost ravnanja javnih oblasti kot element odškodninske odgovornosti javnih oblasti [Unlawfulness of the performance of public authorities as an element of tort liability of public authorities]. In Odgovornost države, lokalnih skupnosti in drugih nosilcev javnih pooblastil za ravnanje svojih organov in uslužbencev [Liability of the state, local communities and other bearers of public authority for the performance of their bodies and officials], pp. 21-27. Edited by Mojca Seliškar Toš. Ljubljana: Inštitut za primerjalno pravo pri Pravni fakulteti.

Public Administration 2020. Development Strategy 2015-2020. 2015. http:// www.mju.gov.si/fileadmin/mju.gov.si/pageuploads/JAVNA_UPRAVA/ Kakovost/Strategija_razvoja_ANG_final_web.pdf (accessed October 20, 2017).

Schuppert, G. F. (2007). Governance Reflected in Political Science and Jurisprudence. In New Forms of Governance in Research Organizations, Disciplinary approaches, Interfaces and Integration, pp. 33-56. Edited by Dorothea Jansen. Dordrecht: Springer. 
Sever, T., Đanić, A., Kovač, P. (2016). Effective legal protection against the excessive length of administrative decision-making: the cases of Slovenia and Croatia. The NISPAcee journal of public administration and policy, 9(1), 135-166.

Sever, T. (2015). Odgovornost države in javnih uslužbencev za škodo [Liability of the state and public officials for the damage]. Javna uprava 51(1/2), 119-138, 178-179.

Sever, T., Rakar, I., Kovač, P. (2014). Protecting Human Rights through Fundamental Principles of Administrative Procedures in Eastern Europe. DANUBE, Law and Economics review 5(4), 249-275.

The Principles of Public Administration. 2017 edition. SIGMA. http:// www.sigmaweb.org/publications/Principles-of-Public-Administration_ Edition-2017_ENG.pdf (accessed November 24, 2017).

Urbančič, M. (2012). Nepremoženjska škoda zaradi kršitve pravice do sojenja brez nepotrebnega odlašanja [Non-pecuniary damage due to violation of the right to a trial without undue delay]. Pravna praksa 31(5), II-VIII.

Vanebo, J. O., Andersen, J. A. (2014). Principles of public management in Scandinavian countries: a theoretical assessment. Mednarodna revija za javno upravo = International public administration review. 12(1), 9-23.

Venice Commission - European Commission for Democracy through Law. 2011. Stocktaking on the Notions of »Good Governance» and »Good Administration«, Study No. 470/2008, CDL-AD(2001)009.

Virant, G. (2015). Strokovna kodifikacija standardov evropskega upravnega prostora v SIGMINIH "načelih javne uprave" in njen vpliv na slovensko javno upravo [Codification of standards of the European administrative space through Sigma's public administration principles and their influence on the Slovenian public administration]. Paper presented at the XXII. Dnevi slovenske uprave, 24 - 25 September. Ljubljana, Slovenia (pp. 1-14).

Virant, G. (2010). Odgovornost predstojnikov za zakonitost upravnega postopka [Liability of the heads for the lawfulness of administrative procedure]. Javna uprava 46(1-2), 57-68, 388-389.

Woehrling, J.-M. (2006). Judicial Control of Administrative Authorities in Europe, Toward a Common Model. SIGMA. 


\section{Odgovornost in pravica do odškodnine v primeru kršitve načel odgovornosti in dobrega upravljanja}

Spridružitvijo EU države članice postanejo del evropskega upravnega prostora, kjer veljajo določena skupna pravna načela, pomembna za delovanje javne uprave na nacionalni ravni. Kot temeljne prvine koncepta dobrega upravljanja, ki določajo standarde za delovanje javnih uslužbencev, lahko izpostavimo zlasti zanesljivost, predvidljivost, odgovornost in transparentnost (SIGMA, 1999). Govorimo o štirih skupinah temeljnih načel evropskega upravnega prava, ki vključujejo načela procesne ali materialnopravne narave (npr. načelo zakonitosti, zaslišanja stranke, odprtosti, spoštovanja rokov, enakosti pred zakonom ipd.).

Pričujoči članek se osredotoča zlasti na ožji, pravni koncept dobrega upravljanja, tj. pravico do dobre uprave, ki preko nabora posameznih pravic in obveznosti vključuje različna temeljna načela in procesna jamstva, ki morajo biti na voljo strankam postopkov. Značilno za evropski prostor je, da so temeljna upravna načela in postopkovna pravila v večini držav članic EU določena z zakonom, ki ureja upravni postopek. Slednji je temeljno orodje države pri oblikovanju in izvajanju javnih politik. Z njegovo pomočjo država rešuje konflikte med javnim in zasebnimi interesi, s poudarkom na omejevanju absolutne oblasti in spodbujanju učinkovitosti javnih politik. Prispevek obravnava odgovornost oblastnih organov in javnih uslužbencev, ki pa ni nujno regulirana kot načelo ali pravilo znotraj zakona, ki ureja upravni postopek, temveč lahko izvira že iz ustave ali druge sistemske zakonodaje. V luči tega prispevek analizira načela in pravila odgovornosti, kot izvirajo iz različnih mednarodnih dokumentov, pomembnih za evropski upravni prostor. To so na primer Načela javne uprave, izdana v okviru pobude SIGMA (EU; OECD, 2017); Pregled konceptov dobrega upravljanja in dobre uprave s strani Beneške komisije (Svet Evrope, 2011); Listina Evropske unije o temeljnih pravicah (EU, 2010); Priporočilo Odbora ministrov CM/Rec(2007)7 državam članicam o dobri upravi (Svet Evrope, 2007); Bela knjiga o evropskem upravljanju (Evropska komisija, 2001); Priporočilo Odbora ministrov R (84) 15 o javni odgovornosti (Svet Evrope, 1984). Članek umesti slovensko ureditev znotraj načel javne uprave, kot so zahtevana v evropskem upravnem prostoru tudi v luči Strategije razvoja javne uprave 2015-2020.

Z upravnoprocesnega vidika k odgovornemu delovanju javne uprave prispevajo različna procesna jamstva, kot so zakonitost, enakost, neodvisnost, sorazmernost, pravna varnost ipd. V drugem delu prispevka je tako poudarek zlasti na analizi odgovornosti javnih uslužbencev, ko le-ti vodijo upravne postopke. Članek poudarja kot odgovorno ravnanje javnih uslužbencev tudi učinkovito upravno odločanje. To pomeni, da morajo biti upravni postopki 
vodeni zakonito in odločitve sprejete $v$ razumnih rokih. Za primere, ko pride do kršitve pravnih načel ali pravil, mora država prepoznati odgovornost in imeti na razpolago učinkovite nadzorne sisteme, ki nudijo strankam učinkovita (pravna) sredstva (kot so na primer pritožba na resorno ministrstvo, upravna inšpekcija, sodna kontrola, ustavna pritožba, pravica do odškodnine ipd.). $\checkmark$ primeru zamud in neučinkovitih domačih pravnih sredstev lahko to med drugim pomeni tudi kršitev 6. in 13. člena Evropske konvencije o varstvu človekovih pravic, kar lahko pripelje do obsodbe države pred Evropskim sodiščem za človekove pravice in posledično plačila odškodnine oškodovanim strankam postopkov. Vsekakor pa velja poudariti, da vsaka kršitev načel ali pravil postopkov še ne pomeni protipravnosti in posledično odškodninske odgovornosti.

Ključne besede: odgovornost, upravni postopek, odškodnine, javni uslužbenec, Slovenija, dobro upravljanje. 